\title{
Application of Affective Engineering Method to Discuss the Social Function of Urban Water-Amenity Landscape
}

\author{
Connie Yixuan Zhang and Yoshida Tokuhisa
}

\begin{abstract}
Nowadays, river conservancy and polluted/waste river reclamation had already become a significant task in city planning, as well as the re-construction of urban river channels. Different from the former river reclamation method which applies concrete bank construction, a new concept of "water-amenity park" is considered as a river-reconstruction method due to the concept of "affective engineering". In this research, a systematic method based on affective engineering is developed to estimate urban water-amenity; 3 representative river-based water-amenity parks were selected to be estimated.
\end{abstract}

Index Terms-Affective engineering, urban river plan, water-amenity, water environment.

\section{INTRODUCTION}

\section{A. What is Water-Amenity}

The term of "water-amenity" ("Shinsui" in Japanese) was proponed in the 25th meeting of Japan Society of Civil Engineers in 1970. Different from the former concepts of "river flow" and "water safety" for river maintenance, "water amenity" emphasizes the function of water surface that provides possibility for people to touch and play. In the "Tokyo City Planning Glossary" (1992), "Water-amenity park" is defined as "The urban waterfront park and green space which opens to citizens and provides the function to make them familiar with water" [1] .

The first water-amenity park originated in Japan as the Furukawa Water-amenity park which was built in 1974 and introduced to the world in the UNEP in Nairobi in 1982, it is considered as a typical case of polluted urban river reconstruction. From then on, water-amenity park has begun to provide an alternative way for urban water environment conservation, different from the traditional purification and high concrete banks.

Due to the combined human-river-nature relationship which can be traced from traditional Asian philosophy of "sense of oneness with nature", water-amenity landscape also emphasizes the visitor's behavior and satisfaction [2].

\section{B. Concept of Affective Engineering ("Kansei" Engineering)}

Affective engineering, also called "Kansei engineering", focuses on the relationship between the physical traits of product and its affective influence on the user. Affect is a general term for a set of psychological processes and situation including emotions, moods, affective impressions

Manscript received May 13, 2014; revised July 8, 2014.

The authors are with the Graduate School of Environment and Energy Engineering, Waseda University, Nishi-Tomida 1011, Honjo, Saitama, 367-0035, Japan (e-mail: connieyxz@ fuji.waseda.jp, toc_yoshida@waseda.jp). and attitudes.

"Kansei" in Japanese refers to the instantaneous feeling and emotion that human experience when interacting with things, such as products and services. According to Mitsuo Nagamachi who is the founder of affective engineering ("Kansei engineering"), "Kansei" is "the impression somebody gets from a certain artifact, environment or situation using all the senses of sight, hearing, feeling, smell, taste, balance, etc., as well as the recognition" [3]. For the example of production management, by the time when customers become consciously aware of what they like, their unconscious has already decided using the sensory information received. The conscious mind then pieces together a "logical" story to justify the decision. "Kansei" occur naturally in all things; products and services evoke feelings of some form whether those feelings are strong, weak, desirable or undesirable. In other way, because the aim of affective engineering is customers' satisfaction, affective engineering usually doesn't refer to a kind of detail technology or technological improvement without the element of emotion. Therefore, in the research and application of affective engineering, usually the theories and methods of marketing and management are applied more than technological theories.

Affective engineering is also a simple methodology for ensuring the product or service evokes desirable emotional responses. The process allows producer to model customer's instantaneous feelings and emotions and subsequently translate them into design parameters [4].

\section{Cultural Environment Technology: Application of Affective Engineering in Civil Engineering}

According to S. Takebayashi, the application of affective engineering in civil engineering can be expressed as "Cultural Environment Technology", as known as "Fudo technology". Nagamachi also clarified that cultural environment technology is the application of affective engineering in the area of civil engineering [5]. "Fudo" is combined by "Fu" (wind) and "Do" (earth), this word refers to the humanity, historical, cultural and social elements of environment. Takebayashi states that the same analogy exists in the concept of cultural environment and affective engineering. Affective engineering promotes the action of productivity from heart, loosens the hardness of logical thinking, deepens the spirit and sensitivity; cultural environment technology relies on the culture of a region, and it effects to soften the severity of life to form a local identity. Furthermore, the driving force of affective engineering comes from the width and power of feeling, in the case of cultural environment technology, the driving force comes from the intelligence and love of a region. This phenomenon also leads to the same analogy. 
Moreover, affective engineering and cultural environment technology both require abilities of thinking, insight observation, imagination, intuition, analytical skills, discernment, imagination from different viewpoints, associative sensitivity, richness of expression, ideas towards flexibility, ingenious thinking, etc. Same as affective engineering, cultural environment technology also has a very large productivity.

As Nagamachi mentioned, affective engineering should contribute to "translate the affective image to the level that is able to be designed to specific matter", cultural environment technology also specify the identity and individuality of local culture. Furthermore, the soft area of cultural environment technology also includes events, maintenance, potential to become heritage, application and storage of variety of useful information, etc. [6].

\section{Water Amenity: Cultural Environment Technology in River Maintenance}

According to the development stages of affective engineering, cultural environment technology and modern water-amenity appear in the similar time period, the development time-period can be summed up as Table I.

Tracing the development of water amenity, it's possible to conclude that the theoretic background, analogy and development stages of affective engineering, cultural environment technology and modern water-amenity trend to the same direction.

\section{METHOD}

\section{A. Kano Model}

To analyze and prove the attribute of affective engineering of water-amenity maintenance method, Kano model - a widely-used basic model of affective engineering - will be applied as tool to analyze water-amenity landscape.

As one of the major areas of ergonomics, affective engineering develops its method system not only in engineering but also due to psychology and marketing.

One of the most influential methods is Kano Model which was developed in the field of quality management by Noriaki Kano in 1984 [7]. Since the late 1970s and early 1980s, Kano and his colleagues set the foundation for a new approach for customer satisfaction modeling. Kano Model is used to establish the importance of individual product features for the customer's satisfaction and hence it creates the optimal requirement for process oriented product development activities.

Kano model is usually applied in industrial design and quality management. Actually, the special emphasis of both Kano model and attractive engineering is customer satisfaction. Therefore, Kano model is usually applied to analyze and evaluate attractive engineering. If the basic attribute of water-amenity park refers to attractive engineering, it is also applicable for Kano model.

Kano Model was originated from the Two Factor Theory proposed by behaviorist Herzberg. Based on the relative correlation between the two coordinates, Kano's two-dimensional quality divides service qualities into:

1) Must-be quality: the attribute doesn't lead to satisfaction when it is sufficient, but result in dissatisfaction when not fulfilled. Since customers expect these attributes and view them as basic, then it is unlikely that they are going to tell the company about them when asked about quality attributes.

TABLE I: DEVELOPMENT STAGES OF AFFECTIVE ENGINEERING, CULTURAL ENVIRONMENT TECHNOLOGY AND MODERN WATER-AMENITY

\begin{tabular}{|c|c|c|c|}
\hline Time & $\begin{array}{l}\text { Affective } \\
\text { engineering }\end{array}$ & $\begin{array}{l}\text { Cultural } \\
\text { environment } \\
\text { technology }\end{array}$ & Modern water amenity \\
\hline $\begin{array}{l}1970- \\
1975\end{array}$ & $\begin{array}{l}\text { Idea of "Kansei" } \\
\text { brought forward } \\
\text { in industrial } \\
\text { design. }\end{array}$ & $\begin{array}{l}\text { "Cultural } \\
\text { landscape", } \\
\text { theory } \\
\text { started }\end{array}$ & $\begin{array}{l}\text { Nature-oriented } \\
\text { method started in river } \\
\text { reconstruction The } \\
\text { first water-amenity } \\
\text { park: Furukara } \\
\text { water-amenity park } \\
\text { (1974) }\end{array}$ \\
\hline $\begin{array}{l}1975- \\
1980\end{array}$ & $\begin{array}{l}\text { The term of } \\
\text { "Emotional } \\
\text { Engineering" put } \\
\text { forward }\end{array}$ & $\begin{array}{l}\text { "Regionalizatio } \\
\text { n" in civil } \\
\text { engineering }\end{array}$ & $\begin{array}{l}\text { Several water-amenity } \\
\text { parks were built in } \\
\text { Tokyo } \\
\text { Private water-amenity } \\
\text { park also appeared }\end{array}$ \\
\hline $\begin{array}{l}1980- \\
1990\end{array}$ & $\begin{array}{l}\text { The term "Kansei } \\
\text { engineering" and } \\
\text { Kano model were } \\
\text { put forward }\end{array}$ & $\begin{array}{l}\text { "Sustainable } \\
\text { development" } \\
\text { was put forward } \\
\text { in }\end{array}$ & $\begin{array}{l}\text { "100 famous water in } \\
\text { Japan" were selected } \\
\text { Boom of } \\
\text { water-amenity parks }\end{array}$ \\
\hline $\begin{array}{l}1990- \\
2000\end{array}$ & $\begin{array}{l}\text { Steady } \\
\text { development and } \\
\text { increase } \\
\text { affective } \\
\text { engineering }\end{array}$ & $\begin{array}{l}\text { Nature-oriented } \\
\text { method river } \\
\text { maintenance } \\
\text { played the main } \\
\text { role }\end{array}$ & $\begin{array}{l}\text { Water-amenity } \\
\text { landscape was } \\
\text { increasing, developed } \\
\text { in depth and started to } \\
\text { individualize }\end{array}$ \\
\hline $\begin{array}{l}\text { After } \\
2000\end{array}$ & $\begin{array}{l}\text { Maturation of } \\
\text { affective } \\
\text { engineering }\end{array}$ & $\begin{array}{l}\text { The core time of } \\
\text { environment } \\
\text { conservation; } \\
\text { "Recover" and } \\
\text { "renascence" }\end{array}$ & $\begin{array}{l}\text { Maturation of } \\
\text { water-amenity: } \\
\text { Steady development, } \\
\text { widely adopted } \\
\text { Not only for landscape } \\
\text { and city planning, but } \\
\text { also applied in water } \\
\text { quality purification } \\
\text { projects }\end{array}$ \\
\hline
\end{tabular}

2) One-dimensional quality: the attribute leads to satisfaction when it is sufficient, and results dissatisfaction when it's not fulfilled. This sort of attributes is considered as which companies compete for (see Fig. 1).

3) Attractive quality: the attribute results to satisfaction when it is fully sufficient, but do not cause dissatisfaction when not fulfilled. These are attributes that are not normally expected.

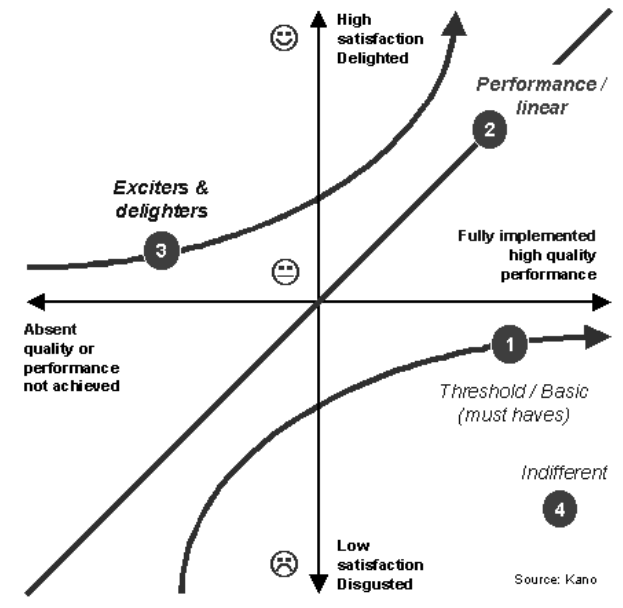

Fig. 1. The one-dimension Kano model. 
4) Reverse quality: this attribute leads to dissatisfaction in some customers when it is highly achieved.

5) Indifferent quality: this attribute refer to the aspects that result neither customer satisfaction nor dissatisfaction.

The analysis method adopts 2-dimensional Kanon model (see Fig. 2) quality element classification table developed by Matzler and Hinterhuber. Based on the cross-comparison of five major elements and the positive and negative choices answered by the respondents, it further categorized the main elements as Table II [8].

TABLE II: TWO-DIMENSIONAL QUALITY ELEMENT CLASSIFICATION TABLE BY MATZLER AND HINTERHUBER

\begin{tabular}{|c|c|c|c|c|c|}
\hline Positive & Like & Must be & Neutral & Acceptable & Dislike \\
\hline Like & $\mathrm{O}$ & $\mathrm{A}$ & $\mathrm{A}$ & $\mathrm{A}$ & $\mathrm{O}$ \\
\hline Must be & $\mathrm{R}$ & I & I & I & M \\
\hline Neutral & $\mathrm{R}$ & I & I & I & M \\
\hline Acceptable & $\mathrm{R}$ & I & I & I & M \\
\hline Dislike & $\mathrm{R}$ & $\mathrm{R}$ & $\mathrm{R}$ & $\mathrm{R}$ & $\mathrm{O}$ \\
\hline
\end{tabular}

M: Must-be; O: One-dimensional; A: Attractive; I: Indifferent; R: Reverse.

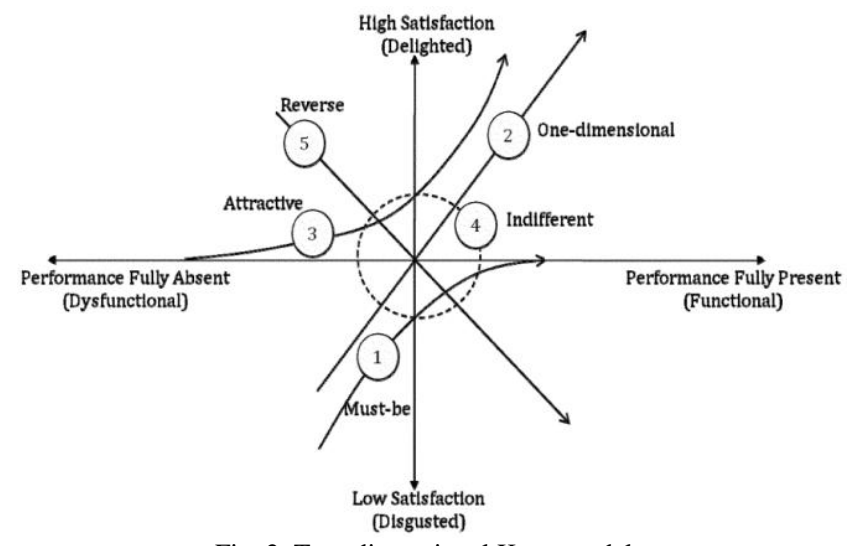

Fig. 2. Two-dimensional Kano model.

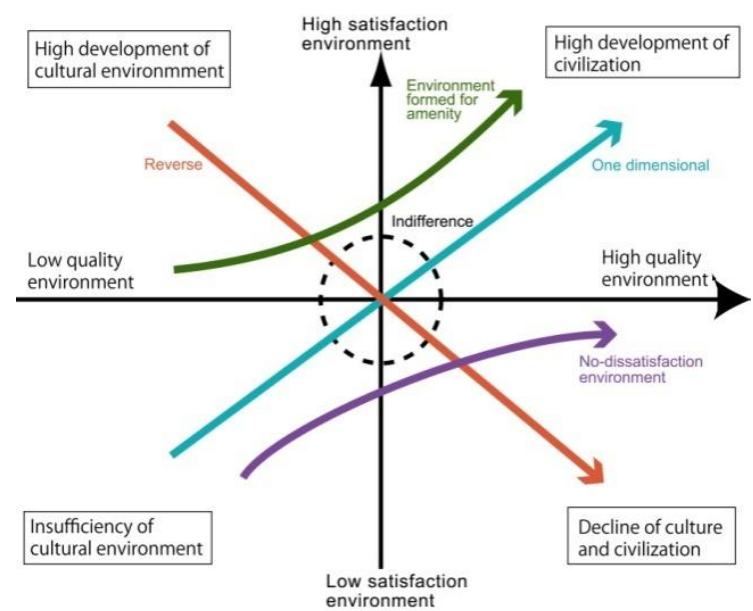

Fig. 3. Kano model for cultural environment technology.

The Kano model is used in order to create attractive products. Different types of quality can be recognized, successful product development means that the development team must meet the basic expectations (the must-be quality) as well as the one-dimensional quality, which correspondents to the expressed expectations a customer has on the products. However, this is everyday work for product designers. What is considerably more complex but necessary is the attractive quality creation in new products. Once an attractive new property is integrated into the product, the customer is surprised and delighted and is tempted to purchase the product.

In the aspect of civil engineering, the Kano model is also available to describe the situation of cultural environment technology and water-amenity. The basement of water-amenity is the development of environment quality that can form the $\mathrm{x}$ axis; $\mathrm{y}$ axis refers to the satisfaction of people towards environment. Successful cultural environment technology and water-amenity development meet the basic expectations, as well as the must-be quality of environment - basic environment quality needs of people; one-dimensional quality then correspondents to the expectations of people has on the environment. The updated Kano model in cultural environment technology can be expressed as Fig. 3.

Tracing the development stages of cultural environment technology and water-amenity, it's also available to derive that water-amenity fits the trace of affective engineering as well as cultural environment technology.

\section{B. Semantic Analysis: Affective Words}

Product semantics is an approach to developing a visual vocabulary in products in order to give them an immediately identifiable set of mainly visual clues (sometimes tactile and auditory), which become tools available to the designer to communicate through their products, helping to reflect function and underlying cultural associations [9].

Nagamachi and many other Japanese researchers use "Kansei word" as a kind of basic data. Even if the procedure of affective engineering at a first glance seems to be strongly dependent on the individual research context, there are in fact similarities in the procedures and the tools used for evaluation [10].

Affective words are the words describing the feature of product. Often these words are adjectives but other grammatical forms are possible. In this research, the domain is clearly fixed to water-amenity landscape, therefore, it's available to make investigation towards visitors in water-amenity parks and sum up the representative affective words.

According to the elements in Kano model and the methodology of semantic analysis, the collection of affective words ("Kansei words") of water-amenity landscape can follow the steps as below:

1) To compare the design of water banks, botany landscape, water quality and general landscape among water-amenity parks, ordinary waterside parks/greenways and other ordinary parks, and sum up the features related to affection;

2) To review the literature of water-amenity landscapes, including news, advertisements, introductions and manuals, related literary works, etc.,

3) In the case study sites, randomly interview visitors (10-20 persons) in each site about their initial feeling of this water-amenity landscape.

4) Conclude the top high-frequency affective words and affective elements.

At all events, the unique facilities of water-amenity parks progress the correlation between visitor's satisfaction and park management. 


\section{Equation of "Amenity Score" for Water-Amenity Landscape}

Matzler and Hinterhuber proposed the index equations of affective engineering based on Kano model as follows [8]:

$$
\begin{aligned}
& \text { Index of increasing satisfaction }=(A+O) /(A+ \\
& O+M+I)
\end{aligned}
$$

Index of reducing dissatisfaction $=(O+M) /(A+$ $O+M+I)(-1)$

A: Attractive, $O$ : One-dimensional, $M$ : Must-be, $I$ : Indifferent.

A minus sign is put in front of the customer satisfaction coefficient of customer dissatisfaction in order to emphasize its negative influence on customer satisfaction if this product quality is not fulfilled. The positive customer satisfaction coefficient ranges from 0 to 1 ; the closer the value is to 1 , the higher the influence on customer satisfaction. A positive customer satisfaction coefficient which approaches 0 signifies that there is very little influence. At the same time, however, one must also take the negative customer satisfaction coefficient into consideration. If it approaches 2 to 1 , the influence on customer dissatisfaction is especially strong if the analyzed product feature is not fulfilled. A value of about 0 signifies that this feature does not cause dissatisfaction if it is not met.

When the satisfaction index value is closer to 1 , it indicates greater influence on customer satisfaction; when the dissatisfaction index value is closer to 1 , it indicates greater influence on customer dissatisfaction. Based on these indices, enterprises can have a better understanding on the most important and beneficial factors when planning or improving services.

Schütte proposed a method to make the degree of attractiveness visible on the base of "Kansei engineering" data that who claims that the overall impression of a product can be estimated in relation to competing products (see Equation 3) [9]. The "Kansei Score" for each "Kansei Word" is added and related to rating of ideal values. Multiplying by 100 gives the percentage certain product rates against the imaginary ideal product. The application of this procedure to a number of different products allows a comparison of the overall impression.

$$
\frac{\sum_{i=0}^{n} \mathrm{KS}_{\text {product }} i}{\sum_{i=0}^{n} \mathrm{KS}_{\text {Ideal } i}} \times 100 \%=\mathrm{SK}[\%]
$$

SK: degree of attractiveness compared to the ideal value

$\mathrm{KS}_{\text {Product } i}$ : Kansei Score for a certain product regarding a Kansei Word

$\mathrm{KS}_{\text {Ideal } i}$ : Kansei Score for the ideal product

$i$ : Consecutive number for Kansei Words

$n$ : Total number of Kansei Words

Based on (1), (2) and (3), (4) can be developed to estimate the degree of attractiveness for water-amenity landscape:

$$
\frac{i}{n} \times \frac{\sum_{i=0}^{n} \mathrm{IS}_{\mathrm{wa}}}{\sum_{i=0}^{n}\left(\mathrm{IS}_{\mathrm{wa}}-\mathrm{RD}_{\mathrm{wa}}\right)} \times 100 \%=\mathrm{SK}_{\mathrm{wa}}[\%]
$$

$\mathrm{SK}_{\mathrm{wa}}$ : Degree of attractiveness of a certain water-amenity landscape
$\mathrm{IS}_{\mathrm{wa}}$ : Increasing satisfaction of a certain water-amenity landscape

$\mathrm{RD}_{\text {wa }}$ : Reducing dissatisfaction of a certain water-amenity landscape

$i$ : Number of virtual affective words

$n$ : Total number of affective words

In the estimation of non-profit water-amenity landscapes Schütte's factor "consecutive number for Kansei words", is changed to the virtual affective words because water-amenity landscape is non-profit and there are not a certain group of customer such like products. Virtual affective words here indicate the words that can clearly describe the affection of visitor, not the general words like "good, beautiful", etc. For visitors of water-amenity landscapes, the non-repeating affective words express the variety and diversity of "Kansei" for water-amenity in their feelings. The $i / n$ rate is multiplied to indicate this factor.

\section{Kano Attributes, Values and the SK Values of each Water-Amenity Landscape}

In the former research of Tsai et al. [11], Kano model and the attributes analysis were applied in the assessment of tourism destinations and services. Based on Tsai's conclusion of Kano attributes in tourism destinations, and according to interview and the analysis towards natural and social functions of each water-amenity landscape, we summed up the indices of the attractive engineering attributes for the quality of the selected water-amenity parks into 25 items, see the table attached. Compared with Tsai's former research, the attributes of water-amenity are modified due to the non-profitable water-amenity park and added more elements on public service. By the analysis based on Kano model, based on the calculation result if IS and RD value, the SK value of each water-amenity landscape can be also summed up as below. It can be concluded that all the items match the positive attributes; none of the site has the reverse attribute.

\section{CASE Study}

\section{A. Case Selection}

There are many small rivers and artificial flume channels in Tokyo. As the urban development progressing, some were dried and filled, especially in the second half of the 20th century. Some rivers were protected and turned into parks, water-amenity parks instead.

In the city planning of Tokyo, there are two main categories of water-amenity spaces: water-amenity park and waterfront greenway. The main difference is management. Water-amenity parks belong to diversity managers such as local government, NGO/NPO and financial groups, etc; Water-amenity greenways usually belong to local government as a part of public landscape in city planning. Moreover, the concept of "water-amenity park" in general meaning also contain lakes, pools and new built waterfront from dry land, other than river channels.

In the research of Minoda and Kuroyanagi (Minoda $\mathrm{T}$. Kuroyanagi A), the maintenance methods of water amenity landscapes can be divided into 3 categories.

1) Category A. Construction:

A1. New built water front from dry land; 
A2. Reconstruction in existed water channel;

2) Category B. Recovery:

B1. Water re-transmission;

B2. Recovery of former river banks and river-side pavements (mainly for common green way):

B3: Eco-biological recovery (mainly for common green way):
3) Category C: Conservation:

C1: Conservation based on the human-water relationship and rebuilding of human amenity facilities; C2: Simple conservation under some regulation (mainly for common rivers);

C3: Historical landscape and heritage conservation.

This research excludes A1 type.

TABLE III: INTEGRATED ESTIMATION SCORES OF WATER-AMENITY LANDSCAPE

\begin{tabular}{|c|c|c|}
\hline Indices & Contents & Score \\
\hline \multirow[t]{5}{*}{ Degree of attractiveness } & $>80 \%$ & 5 \\
\hline & $60 \%-80 \%$ & 4 \\
\hline & $40 \%-60 \%$ & 3 \\
\hline & $20 \%-40 \%$ & 2 \\
\hline & $<20 \%$ & 1 \\
\hline \multirow[t]{5}{*}{ Water quality } & $\mathrm{BOD}<3 \mathrm{mg} / \mathrm{L}, \mathrm{DO}>5 \mathrm{mg} / \mathrm{L}$ (Japanese standard B); underwater visibility $>50 \mathrm{~cm}$ & 5 \\
\hline & BOD $<5 \mathrm{mg} / \mathrm{L}, \mathrm{DO}>5 \mathrm{mg} / \mathrm{L}$ (Japanese standard C); underwater visibility $>40 \mathrm{~cm}$ & 4 \\
\hline & $\mathrm{BOD}<8 \mathrm{mg} / \mathrm{L}, \mathrm{DO}>2 \mathrm{mg} / \mathrm{L}$ (Japanese standard D); underwater visibility $>30 \mathrm{~cm}$ & 3 \\
\hline & $\begin{array}{l}\mathrm{BOD}<10 \mathrm{mg} / \mathrm{L}, \mathrm{DO}>2 \mathrm{mg} / \mathrm{L} \text { (Japanese standard } \mathrm{E}) ; \text { underwater visibility }>20 \mathrm{~cm} \text {, } \\
\text { no odor, no floating materials }\end{array}$ & 2 \\
\hline & $\begin{array}{l}\text { Underwater visibility }>10 \mathrm{~cm} \text {, pale tea color or pale brown color, generally no odor, or } \\
\text { sometimes extremely small amount of odor }\end{array}$ & 1 \\
\hline \multirow[t]{5}{*}{ Landscape diversity } & $\begin{array}{l}\text { Different landscape in four seasons, diversity landscape structure, flower belt, green garden } \\
\text { and cherry blossom, biodiversity (or biotope) }\end{array}$ & 5 \\
\hline & Variety of colors in different seasons or different places; landscape structure, green belt & 4 \\
\hline & High trees, grass and flowers are planted based on green belt & 3 \\
\hline & Continuous green belt alongside water channel & 2 \\
\hline & Only trees and/or grass on banks & 1 \\
\hline \multirow[t]{5}{*}{ Culture and life diversity } & $\begin{array}{l}\text { Cultural landscape construction, playing area, events, clear indication or introduction of this } \\
\text { site or relevant biology knowledge, environmental study and nature observation, obtained } \\
\text { national/local award or dissemination by media }\end{array}$ & 5 \\
\hline & $\begin{array}{l}\text { Cultural landscape construction or playing area, indication or introduction of this site, } \\
\text { possible to get related information from internet, obtained national/local award or } \\
\text { dissemination by media }\end{array}$ & 4 \\
\hline & $\begin{array}{l}\text { Playing area, indication or introduction of this site, possible to search related blog articles or } \\
\text { comments from internet }\end{array}$ & 3 \\
\hline & Indication or introduction only & 2 \\
\hline & No cultural element & 1 \\
\hline \multirow[t]{5}{*}{ Convenience } & $\begin{array}{l}>2 \text { Restrooms, drinking water supply or automatic vending machine, shower, barrier-free } \\
\text { infrastructures, emergency evacuation area, communication area }\end{array}$ & 5 \\
\hline & $\begin{array}{l}>2 \text { Restrooms, drinking water supply or automatic vending machine, barrier-free } \\
\text { infrastructures or emergency evacuation area or communication area }\end{array}$ & 4 \\
\hline & $\begin{array}{l}>1 \text { Restrooms, benches and automatic vending machine / convenience store, small rest area } \\
\text { or communication area }\end{array}$ & 3 \\
\hline & 1 Restroom, and benches & 2 \\
\hline & Benches only, or nothing & 1 \\
\hline \multirow{5}{*}{$\begin{array}{l}\text { Distance to nearest } \\
\text { residential area }\end{array}$} & $0-20 \mathrm{~m}$ & 5 \\
\hline & $20-50 \mathrm{~m}$ & 4 \\
\hline & $50-100 \mathrm{~m}$ & 3 \\
\hline & $100-300 \mathrm{~m}$ & 2 \\
\hline & $>300 \mathrm{~m}$ & 1 \\
\hline
\end{tabular}

In this paper, 3 typical type of water-amenity landscape are selected as case: Furukawa water-amenity park, the first water-amenity park reclaimed completely from former river channel; Kitazawakawa greenway, reclaimed by purified waste water; and Tone canal, partly reconstructed to water-amenity park. Combine with the indices of water-environment elements as water quality and landscape variety and set up the scale of scores as Table III.

\section{B. Case 1: Furukawa Water-Amenity Park}

As shown in Fig. 4 to Fig. 8, Furukawa water-amenity park is the first water-amenity park in Japan and the world. The old Furukawa River was a flume channel. After the urbanization of Tokyo in 20th century, the function of Furukawa River was gradually changed to drainage and considered as "impossible to reclaim". In 1973, Edogawa 
ward started to maintenance the Furukawa system then reconstructed the water-amenity park (see Table IV).

\begin{tabular}{ll} 
TABLE IV: BASIC INFORMATION OF FURUKAWA WATER-AMENITY PARK \\
\hline \hline Location & Edogawa Ward, East Tokyo \\
\hline Length & $1,200 \mathrm{~m}$ \\
Opening year & 1974 \\
Average bank height & $0.3 \mathrm{~m}$ \\
Average water depth & $0.2 \mathrm{~m}$ \\
Bank material & stone \\
Source & Furukawa water purification \\
& plant \\
Mouth & Shinkawa River \\
Water classification & purified river water \\
River system & The Edo River \\
Initial form & flume channel \\
Minimum distance to residential house & $15 \mathrm{~m}$ \\
Maintenance method & B1 \\
BOD & $<2 \mathrm{mg} / \mathrm{L}$ \\
DO & $>5 \mathrm{mg} / \mathrm{L}$ \\
Underwater visibility & $>50 \mathrm{~m}$ \\
Award: & Japan National Construction \\
& Award (1974) \\
5 top affective words: & Relaxation, comfortable, \\
& convenient, easy to use, therapy \\
Water quality score: & 5 \\
Landscape diversity score: & 5 \\
Culture and life diversity score: & 5 \\
Convenience score: & 5 \\
Distance to nearest residential area & 5 \\
score: & \\
Degree of attractiveness score: & 4 (SK: 64\%) \\
\hline \hline
\end{tabular}

Furukawa water-amenity park

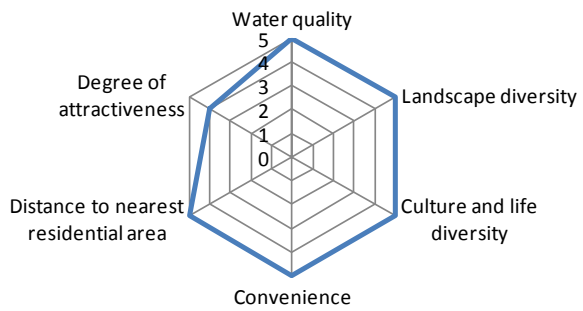

Fig. 4. Comprehensive factors of Furukawa water-amenity park.

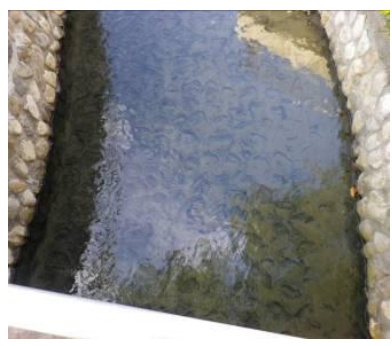

(a)

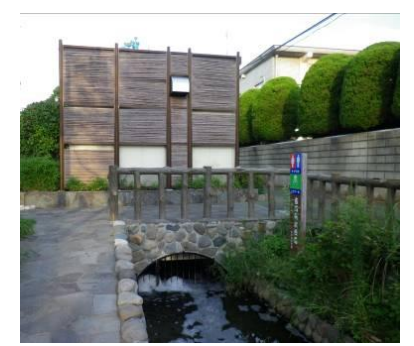

(b)
Fig. 5. Clear water and the purification plant.

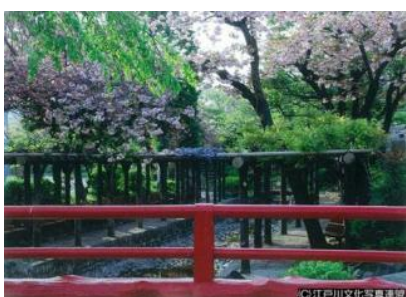

(a)

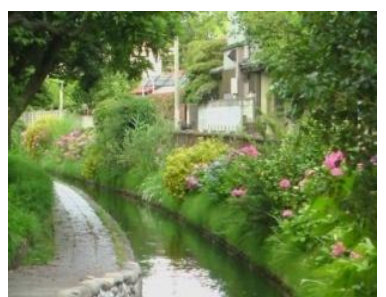

(b)

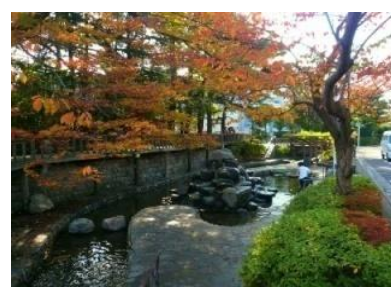

(c)

Fig. 6. Diversity of natural and cultural scenery.

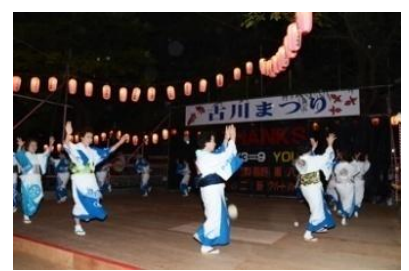

(a)

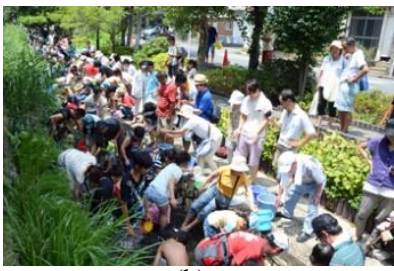

(b)

Fig. 7. Summer events and environmental study are held every year (photo: Edogawa city office) .

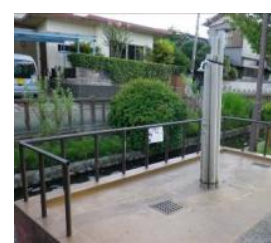

(a)

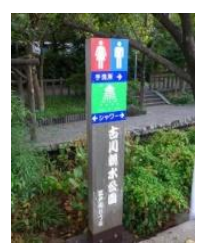

(b)

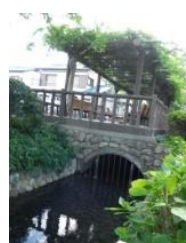

(c)
Fig. 8. Shower area, restroom and communication area.

\begin{tabular}{|c|c|}
\hline Location & Setagaya Ward, Tokyo \\
\hline Length & $2,400 \mathrm{~m}$ \\
\hline Opening year & 1977 \\
\hline Average bank height & $1.5 \mathrm{~m}$ \\
\hline Average water depth & $1.0 \mathrm{~m}$ \\
\hline Bank material & Stone mixed concrete \\
\hline Source & $\begin{array}{l}\text { purified waste water from Ochiai } \\
\text { Water Reclamation Center }\end{array}$ \\
\hline Mouth & The Meguro River \\
\hline Water classification & reclaimed waste water \\
\hline River system & The Meguro River \\
\hline Initial form & Former water supply channel \\
\hline $\begin{array}{l}\text { Minimum distance to } \\
\text { residential house }\end{array}$ & $7 \mathrm{~m}$ \\
\hline Maintenance method & B1 \\
\hline BOD & $<4 \mathrm{mg} / \mathrm{L}$ \\
\hline DO & $>10 \mathrm{mg} / \mathrm{L}$ \\
\hline Underwater visibility & $>40 \mathrm{~m}$ \\
\hline Award: & $\begin{array}{l}\text { The "Handmade Hometown Award" } \\
\text { (offered by Ministry of Land, } \\
\text { Infrastructure and Transportation) } \\
\text { (1996) }\end{array}$ \\
\hline 5 top affective words: & $\begin{array}{l}\text { Greenbelt, relaxing place for residents, } \\
\text { environment friendly, good running } \\
\text { and cycling way, therapy }\end{array}$ \\
\hline Water quality score & 4 \\
\hline Landscape diversity score: & 5 \\
\hline $\begin{array}{l}\text { Culture and life diversity } \\
\text { score: }\end{array}$ & 5 \\
\hline Convenience score: & 5 \\
\hline $\begin{array}{l}\text { Distance to nearest } \\
\text { residential area score: }\end{array}$ & 5 \\
\hline $\begin{array}{l}\text { Degree of attractiveness } \\
\text { score: }\end{array}$ & 4 (SK: 61\%) \\
\hline
\end{tabular}

\section{Case 2: Kitazawakawa Greenway}

As shown in Fig. 11 to Fig. 13, the Kitazawa River was cut as a tributary of Tamagawa-josui water supply system which 
was built in the middle of 17 th century in order to supply the daily-life water for ancient Tokyo. Same as many other rivers in Tokyo, the Kitazawa River had got polluted water quality as the result of industrialization since the 1950s. In 1995, the project "Restoration of streams in three rivers in the southern downtown area of Tokyo" was started. The reclaimed water after advanced wastewater treatment in Ochiai Water Reclamation Center is fed into the three streams - Shibuya and Furu River, Meguro River and Nomi River, where water was stagnated and stream environment deteriorated in the past. This has contributed to the increase of water volume and recuperation of affluent water environment in the streams (see Table V).

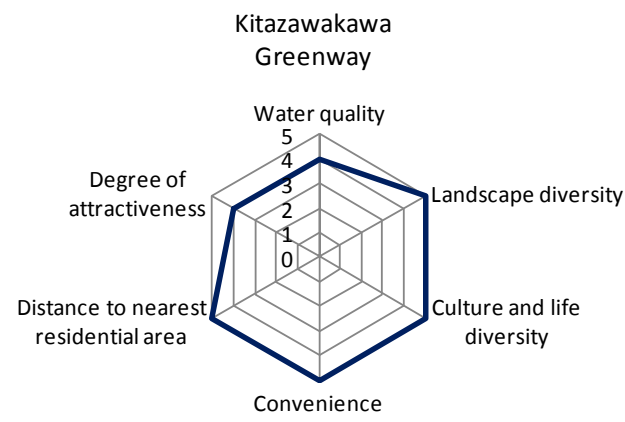

Fig. 9. Comprehensive factors of Kitazawakawa greenway.

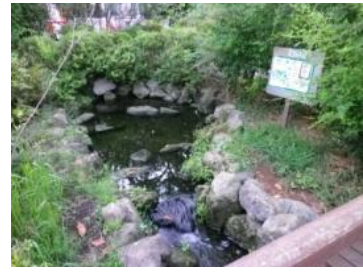

(a)

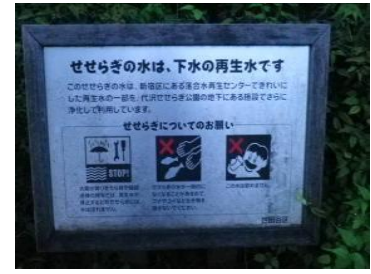

(b)
Fig. 10. Water quality is not so clear; notice board introduces the situation of water purification.

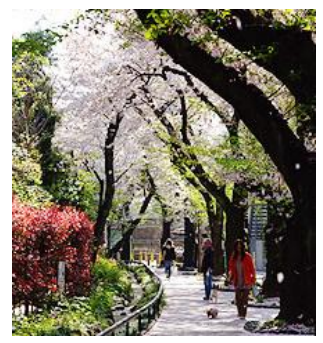

(a)

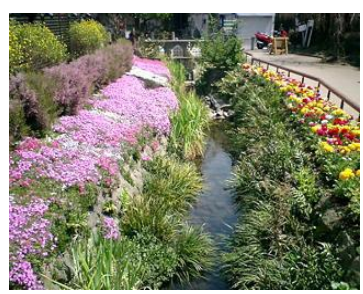

(c)

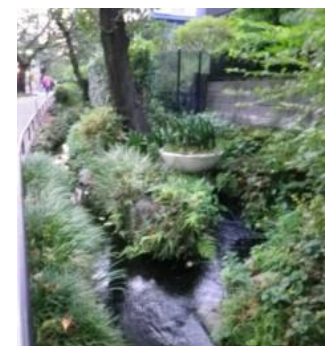

(b)

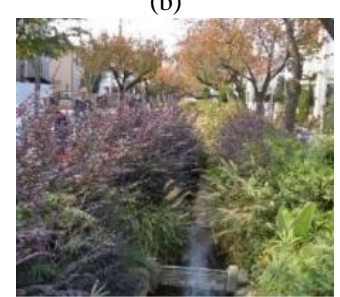

(d)
Fig. 11. Landscape diversity in different seasons.

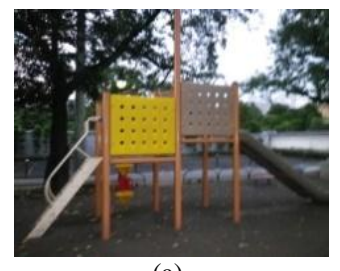

(a)

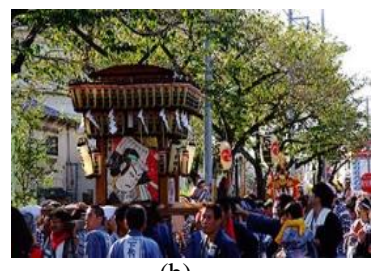

(b)
Fig. 12. Playground and festival event.

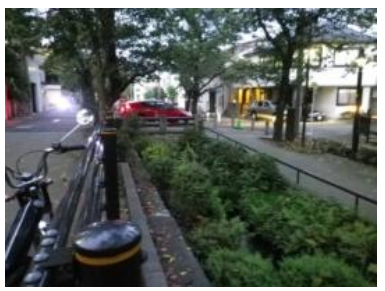

(a)

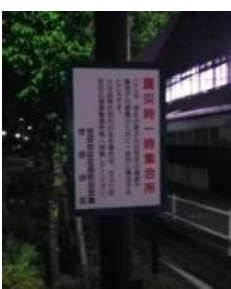

(b)
Fig. 13. Cycling way and emergency evacuation area notice board

\section{Case 3: Tone Canal Water Park}

TABLE VI: BASIC INFORMATION OF TONE CANAL WATER PARK

\begin{tabular}{|c|c|}
\hline Location & $\begin{array}{l}\text { Kashiwa city, Nagareyamacity, } \\
\text { Noda city, }\end{array}$ \\
\hline Length & $8.5 \mathrm{~km}$ (total) $200 \mathrm{~m}$ (amenity area) \\
\hline Opening year & 1890 (total) 2000 (amenity area) \\
\hline Average bank height & $3 \mathrm{~m}$ \\
\hline Average water depth & $1.0 \mathrm{~m}$ \\
\hline Bank material & Grass lawn \\
\hline Source & Tone River \\
\hline Mouth & Edo River \\
\hline Water classification & River water \\
\hline River system & Tone River \\
\hline Initial form & The first western canal in japan \\
\hline $\begin{array}{l}\text { Minimum distance to } \\
\text { residential house }\end{array}$ & $7 \mathrm{~m}$ \\
\hline Maintenance method & B1 \\
\hline BOD & $6.5 \mathrm{mg} / \mathrm{L}$ \\
\hline DO & $7.5 \mathrm{mg} / \mathrm{L}$ \\
\hline Underwater visibility & $>30 \mathrm{~m}$ \\
\hline Awards & $\begin{array}{l}\text { National Civil Heritage (2006) } \\
\text { Industrial Heritage (2007) }\end{array}$ \\
\hline 5 top affective words: & $\begin{array}{l}\text { Famous site, convenient for walking } \\
\text { and cycling, good relaxing place, joy } \\
\text { of events, greenbelt }\end{array}$ \\
\hline Water quality score & 3 \\
\hline Landscape diversity score: & 4 \\
\hline Culture and life diversity score: & 5 \\
\hline Convenience score: & 4 \\
\hline $\begin{array}{l}\text { Distance to nearest residential } \\
\text { area score: }\end{array}$ & 4 \\
\hline Degree of attractiveness score: & $4(\mathrm{SK}: 60 \%)$ \\
\hline
\end{tabular}

The Tone Canal, which was designed by Dutch engineer as the first western canal in Japan, opened in 1890 to connect Edo River and Tone River for transportation, and finished its function of traffic canal in 1941 after railways instead its utility. Thereafter, it was reclaimed as irrigation channel. In 2000, water-amenity maintenance was implemented at the Tone Canal in Nagareyama, as Tone Canal water park. In 2006, Tone Canal was selected as civil heritage in 2006, as industrial heritage in 2007 (see Fig. 14 to Fig. 18).

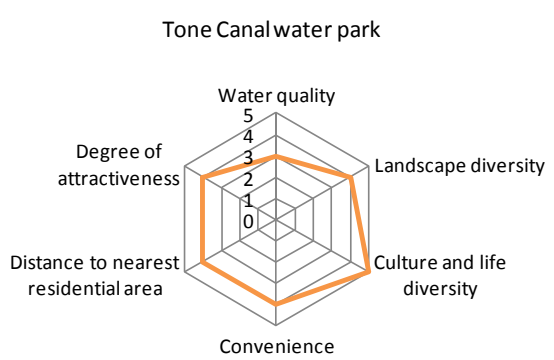

Fig. 14. Comprehensive factors of Tone Canal water park. 


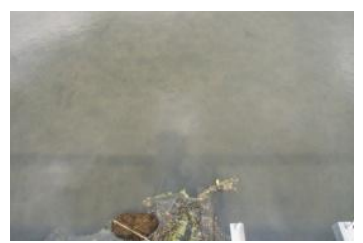

(a)

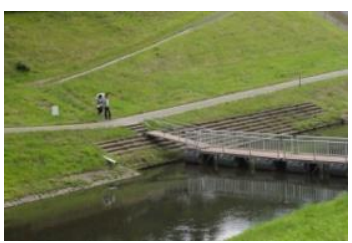

(b)
Fig. 15. Natural water without purification

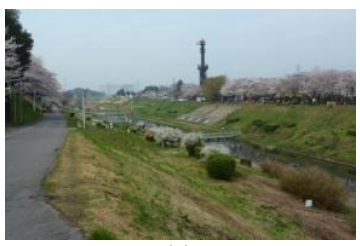

(a)

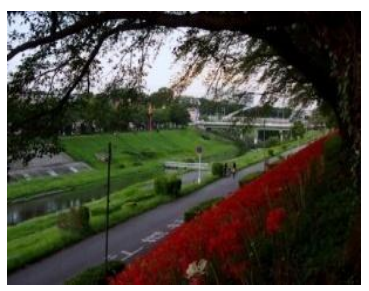

(c)

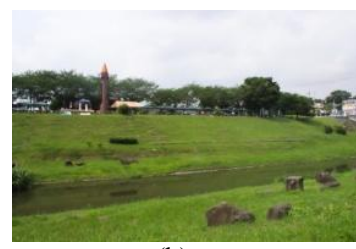

(b)

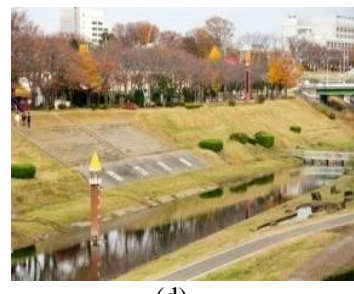

(d)
Fig. 16. Diversity of landscape in different seasons.

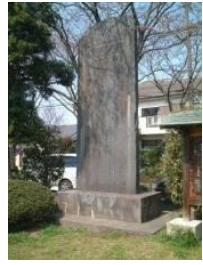

(a)

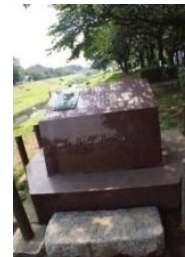

(b)

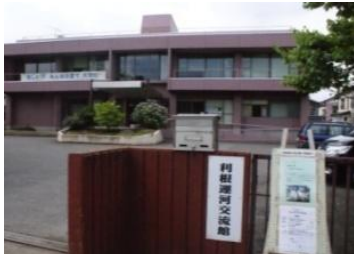

(c)
Fig. 17(a). The monument of Tone Canal ; (b). The designer Anthonie Mulder; (c). TTone Canal Communication Museum.

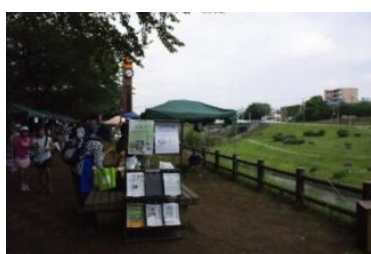

(a)

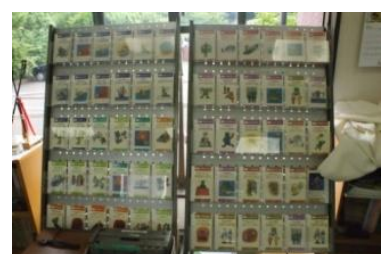

(b)
Fig. 18. Monthly market and flyers.

\section{CONCLUSION}

Today, many city planners meet challenges that force them to put strong emphasis on integrating affective aspects in their product design as well. This study has demonstrated the ability of the affective engineering methodology to evaluate, improve and validate water-amenity landscapes towards the desired impact.

Advantages of using affective engineering are that abstract feelings are visualized and made comprehensible. Thus, it may provide a structured support for integrating affective values into product design, especially in early and late stages of the product development process. However, performing full affective engineering studies takes time, resources and special competence of the facilitator.

\section{REFERENCES}

[1] S. Tsuboi, "Water policy and river management: Evaluation of urban water parks considering environment and disaster prevention functions: a case study of Edogawa Ward, Tokyo," Journal of Water and Environment Issues, vol. 20, pp. 55-62, 2008.

[2] Architectural Institute of Japan, Essays of Water-Amenity Engineering, Tokyo: Shinzansha Scitech Press, pp. 1-6, 2002.

[3] M. Nagamachi, Product Development and Kansei, Tokyo: Kaibundo, 2005.

[4] M. Nagamachi, "Kanseiengineering," Tokyo: Kaibundo, 1989.

[5] J. Yasokawa, N. Takahashi, and T. Ojima, "A study on diverted conditions of abolished rivers and streams in the district of Tokyo," Journal of Architecture Planning Environment, no. 508, pp. 21-27, 1998.

[6] S. Takebayashi, The Renaissance of Fudo in 1000 Years, Tokyo: 21Life Publication, 2013.

[7] N. Kano, Guide to TQM in Service Industries, Tokyo: Asian Productivity Organization, 1996, pp. 15-21.

[8] K. Matzler and H. Hinterhuber, "How to make product development projects more successful by integrating Kano's model of customer satisfaction into quality function deployment," Technovation, vol. 18, no. 1 , pp. 25-38, 1998.

[9] S. Schütte, "Engineering emotional values in product design," Stockholm: Linkoping Studies in Science and Technology, Dissertation 951, 2005.

[10] M. Nagamachi, "Kanseiengineering in consumer product design,"Ergonomics in Design, vol. 10, no. 2, pp. 5-10, 2002.

[11] Tsai et al., "Application ofkano model to discuss tourist demands on service quality in recreational travel," International Journal of Computer Science and Network Security, vol. 11, no. 3, pp. 249-254, 2011.

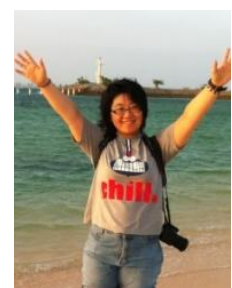

Connie Yixuan Zhang was born on March 15, 1983 in Des Moines, IA, USA with Chinese nationality. She is a Ph.D. candidate of environmental policy studies in the Graduate School of Environment and Energy Engineering, Waseda University. She got a bachelor degree of art in 2004 from Tsinghua University and master degree of philosophy in 2007 from Chinese Academy of Science.

She also works as a research assistant in the Department of River, Pacific Consultants Co. Ltd, Tokyo.

Ms. Zhang is also a member of Center for Environment Information Science, Japan, the Japan Association of Comparative Culture, Association for History of Science and Technology, China, and Chinese Translators' Association. 